\title{
CRIANÇAS BICHAS DEMASIADAMENTE FABULOSAS
}

\author{
Alexsandro Rodrigues \\ Steferson Zanoni Roseiro ${ }^{\mathrm{ii}}$ \\ Jésio Zamboniiii \\ Castiel Vitorino Brasileiro ${ }^{\text {iv }}$ \\ Mariamma Fonseca Santanav
}

\section{Resumo}

Trabalhando a vida bicha enquanto fábula, esse texto não apresenta objetivos bem definidos ou mesmo regras de leitura, mas, antes, apenas nuances de corpos e possibilidades de existência. Aqui é possível ler começando pelo meio ou por uma das extremidades, nada disso importa. Há três fábulas e um aviso por um leitor desavisado, e, em todas as partes, encontram-se bichas, corpos demoníacos, reinos fugidios e vidas comunitárias. Em uma das fábulas, é possível que o corpo seja arremetido a processos de vida poligâmicos e de políticas de amizade impensáveis no contexto da sociedade consumista-familiar; noutra, é a arte peralta endemoniada que importa como ponto de afeto; há, ainda, o convite à própria fabulação praticável com os corpos-criança que escapam de escafandros por desbotarem. Assim, portanto, a história não começa, mas é anunciada: algo se passa aqui e de nada importa. Serve apenas de convite à vida bicha demasiadamente fabulada.

Palavras-chave: Bicha. Fábula. Criança. Segurança.

\section{Abstract}

Exploring the fag life as fables, this essay does not introduce any defined objectives or even a reading guidance, but, first, shows some bodies nuances and existential possibilities. The reading may starts by the middle or by any of its extremities; it is not a question to worry. There are three fables and a warning from an unaware reader and, in all of that, there lay some fags, demonic bodies, fugitive kingdoms and community life. In one of the fables, bodies may be related to processes of polygamous life and to the friendship polices unthinkable in the parentalconsumerist society. In another, it is the demoniac mischievous art that matters to the writing for its affective capacity. Still, but not last, there is an invitation to the fabling, an invitation to get away from the diving suit fading with the childish-bodies. Therefore, the story does not begin but it announces there is something going on but it does not matter. It is just an invitation to the fag life overly fabled.

Keywords: Fag. Fable. Child. Safety. 


\section{Aviso (por um leitor desavisado!)}

O que você tem em mãos não é exatamente um artigo acadêmico, pelo menos não o que costumeiramente se exige de um. Se você chegou a esse texto e espera encontrar um objetivo, uma estratégia metodológica, uma conclusão e um monte de considerações típicas da economia acadêmica, aconselhamos que logo feche esse texto ou, então, deixe-se surpreender. Aqui, desenrolam-se três fábulas cuja realidade é potência, que insistem além de existir. Fábulas que, por inventarem crianças bichas, berram existências impensáveis e iminentemente imanentes. Nada temos a oferecer senão essas três fábulas de corpos desbotados, demoníacos e embichados; três fábulas para serem lidas em ordem qualquer, para serem risadas e nada procurarem. Apenas a primeira delas recorre aos saberes acadêmicos indiretamente, em notas de rodapé, a fim de situar nesse terreno tantas vezes inóspito à fabulação um pouco de onde viemos e para onde vamos. Mas o que importa mesmo é o que se passa. Se nos cabe algum pedido ainda a quem quer que chegue esse texto, por favor, levem-nos a sério tanto quanto na brincadeira! Nosso desejo com essas breves intervenções é que as infâncias e as sexualidades possam ser pensadas e vividas de outras maneiras, que outras políticas de existência possam se firmar pela afirmação da vida como multiplicidade. Há, aqui, apenas vidas bichas demasiadamente fabuladas.

\section{O Reino do Arco-Íris: delírios de um escafandro}

Era uma vez um lugarvi em que as crianças ${ }^{\text {vii }}$ escapavam aos sistemáticos sequestros ${ }^{\text {viii }}$ por uma série de instituições. Esse mundo fabulosoix, cheio de feitiços e encantos arrogantes e astuciosos, traça o contraponto ao mito de uma infância pura e intocável ${ }^{\mathrm{x}}$, pretenso paraíso perdido da humanidade deturpada. Ali, as ruas movediças surgem na ponta das línguas, só existindo enquanto sinais quaisquer são lançados à deriva, no exato intervalo entre a boca que se abre e a palavra que ecoa. Em virtude dessa exótica configuração, o lugar é chamado Reino do Arco-Íris. Nesse reino sem rei e sem demarcações estáticas, os corpos ${ }^{\mathrm{xi}}$ se incorporam ${ }^{\mathrm{xii}}$ com vigor instantâneo, imediatos como a travessia de um portal mágico. Tais feitiços velozes são como aqueles que fazem alguém se tornar adulto a partir de certa idade, algo bem diferente das lentas mudanças na carne e nos ossos. Um reino todo feito de passagens...

Mesmo havendo tantas vias, inúmeras, muitos lá jamais pisaram. Foram seduzidos e sequestrados por vidas adultas, vidas maduras, no limiar da podridão e cheias de fantasmas! Pretérito mais que perfeito: tinham deixado a criancice de lado, afirmando-se responsáveis pela negação das alegrias. Foram demasiadamente comportados, sob medida e com reforço, em uma história muito bem contada, tantas vezes recontada que passou a existir xiii.

Os habitantes do Reino do Arco-Íris eram incorpóreos corpos cheios de jeitos, trejeitos e ajeitos... cores, sabores e odores... de modo que tudo o que lá existia se movia incessantemente de um modo estranho, telepático, como a velocidade mais veloz, o súbito incomensurável. Então, se alguém disser que está agindo como criança, talvez essa seja uma senha de passagem para o Reino do Arco-Íris. Não perca a chance de atravessá-la, pois ela desaparece mais rápido que um piscar de olhos. Tendo atravessado o signo e sustentando o movimento incessante a seguir, passa-se a fabricar um corpo criança, infâncias se inventam ${ }^{\mathrm{xiv}}$.

Atraídas, as crianças estão em trânsito constante, experimentam o que os reinos de verdade querem lhes impedir. Algumas, que se supõe estarem protegidas pelas governanças e bem-dispostas em organizações, são vistas tímidas turistas do Arco-Íris. Outras, camaleonicamente fogem, como um turbilhão, para onde a vida insiste em escapar. E, em suas camaleonices, fazem toda boa segurança fugir. $E$ tanto fogem que nem sequer suas genitálias permanecem! Suas camaleonices fazem-nas indetectáveis entre meninos e meninas. E, assim, 
metamorfoseiam-se bichas ${ }^{\mathrm{xv}}$. Na imperceptível inquietude ou na agitação incansável ou, ainda, em algum ponto qualquer entre estas duas pontas do Arco-Íris, um local onde a criança pode insistir emerge para recebê-las.

Quando seduzidas pelo Adultério - o reino dos adultos que traíram a própria crianceria em busca das promessas de poder, completude e conforto no invivível ser sempre "igual" -, os corpos tornam-se estátuas atônitas, parecendo formas eternas e imutáveis. Mas sentem, constante e inevitavelmente, a impossibilidade e a dificuldade de permanecerem imóveis. As crianças, porque bichas, perturbam! Atrevidas, elas vivem o tempo que podem, a potência de existir em monstruosidades ${ }^{x \mathrm{i}}$, convocando, seduzindo, espezinhando para que todos entrem com elas no Reino do Arco-Íris.

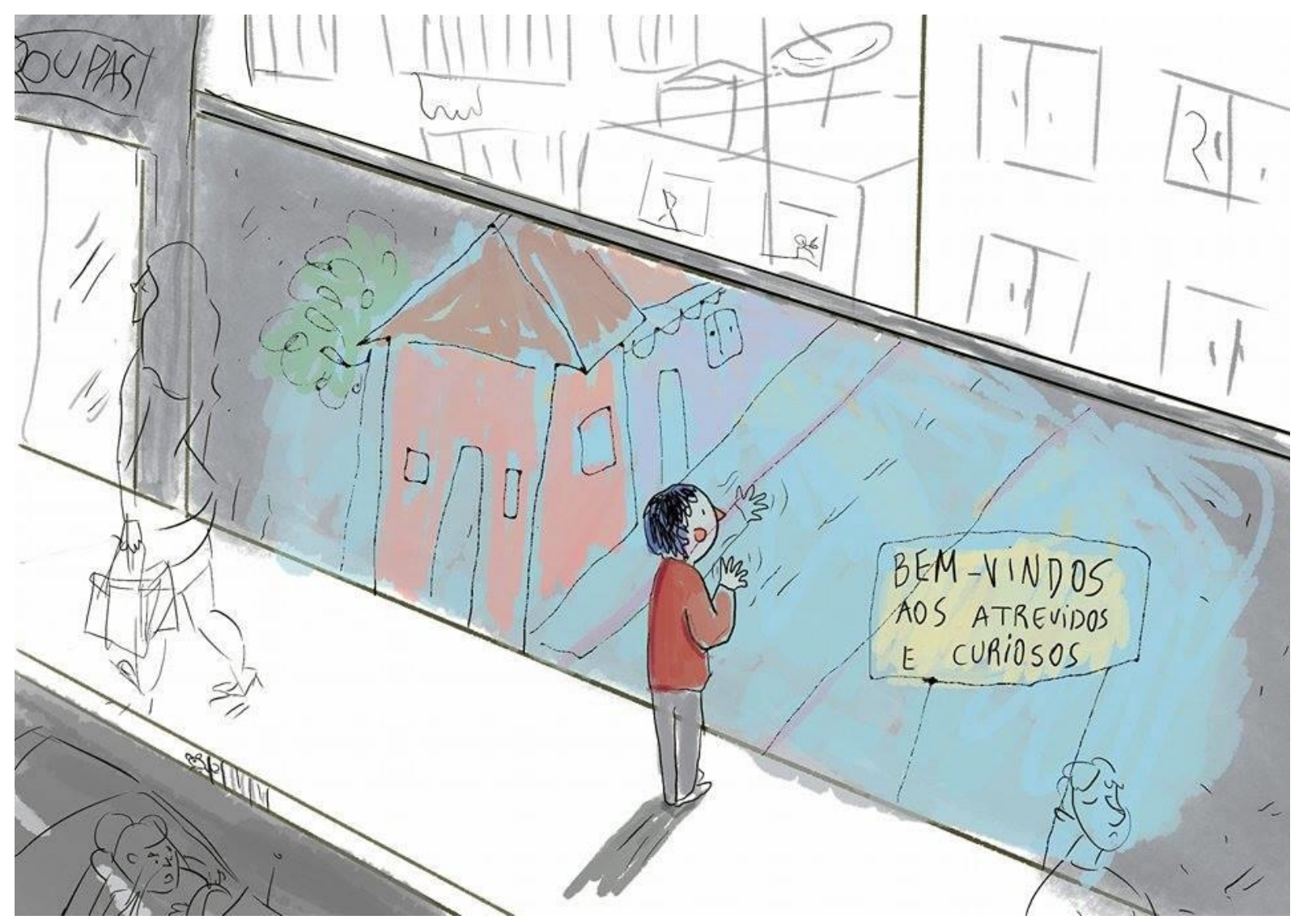

Bem-vindo aos atrevidos e curiosos!

Ora, nesse reino desreinado e encantado das crianças sempre se pode chegar de alguma maneira. Diabolicamente, está em todo lugar, em potência. Atentemo-nos para essas criadoras criaturas que circulam entre nós, que nascem em meio a tanta segurança e expectativa, a tantos planos de que serão meros produtos reprodutores dos ideais de um sobrenome tornado propriedade privada. Elas decepcionam a toda hora, frustram as expectativas paternas e sociais e dão muito, mas muito trabalho - mesmo! - para serem domadas e adestradas. Ainda assim, depois de tudo quanto é enquadramento, elas borram, pintam e bordam. Aprendem, desde sempre, artes da bichice. Daí que, quando atacam, espantamo-nos com elas. Logo dizemos serem de outros planetas! E, ainda que possam se conectar com outros planetas (outros mundos, outros seres, outras vidas...), as crianças não falam uma língua estrangeira, falam a nossa nas próprias brincadeiras, em seus feitiços 
cotidianos. Inventam jeitos de dizer que perturbam as ordens gramaticais, são das maiores inventoras da língua.

Com elas, o tempo rói sua própria cauda e espanta o calendário-ano dos reinos seguros. O espaço torna-se extremamente volátil e, ao mesmo tempo, o mais denso possível. No Reino do Arco-Íris, o tempo tem sempre uma contagem diferente, um ritmo diferente, um respirar diferente. O espaço, por outro lado, nunca se encontra onde é procurado, está sempre além, na ultrapassagem. Irrequietas e nervosas, as crianças adoram saber que podem se deslocar incessantemente, tornando o reino sempre outra coisa. Frenéticas, adoram passear e assustar a pretensa calmaria dos reinos seguros!

Não há lugar ou forma que segure esses corpos. Corpos obesos, magricelas, musculosos, altos ou baixos. Corpos femininos ou dissimuladamente "másculos", corpos travestidos, corpos carnavalescos, corpos mimetizados. Em se tratando de tonalidades, novas paletas tiveram que ser inventadas para aquelas crianças, pois os contrastes racistas foram perdidos em tons de roxo, de púrpura, de magenta, violeta, azul, verde, oliva, escarlate, pérola. Os cabelos, em uma miríade de arquiteturas, fazem espetáculos. Crianças podem ser tão cabeludas que chegam a não ter mais cabelo. $E$ nem sequer precisam! Há muito desenvolveram, enquanto bichas, a arte de confeccionar perucas e, pela cidade, reinam os desfiles mais exuberantes de camisas, toalhas, sacos plásticos e todo e qualquer tipo de material que possa fazer as vezes de cabelo.

Com tantas invenções assim, reinam os usos, desusos, reúsos e abusos. Como toda criança bem sabe, há, nos restos, nas sucatas, toda uma nova vida a fabular. Pode-se nelas encontrar referências aos heróis, à música, ao cinema, à literatura, ao teatro... ou qualquer outra coisa! Pois elas devoram tudo, apropriam-se desejosamente em vez de meramente assimilar, ou seja, elas transformam tudo que engolem, para não se tornarem depositárias de uma cultura morta. Fazem feitiços com o inócuo e fazem divas reencarnarem! Refazendo seus corpos dessa maneira, elas se metamorfoseiam inúmeras vezes, escapando a identificações e reconhecimentos.

Seja como for, as crianças fazem-se fantásticas estrelas candentes. Ligeiras e faceiras, elas recusam as promessas de serem o futuro da pátria, de carregarem o fardo familiar, feitas pelos reinos seguros. Elas ousam existir como um processo insistente, em vez de ficarem aguardando imóveis e protegidas o dia em que poderão ser. A seu bel-prazer, prometem apenas o infortúnio das confusões, das tagarelices, das bichices e das armações.

Astuciosas, riem de toda tentativa de domá-las pelo medo, enfrentando audaciosas as morais das fábulas xii. Há muito aprenderam o heroísmo das bruxas e a vilania dos mocinhos, e não se deixam ser capturadas pela literatura infantilizadora, aquela que pretende dizer o que pensar e o que sentir. Riem, debocham e saltitam, bem aos modos do Saci, da Cuca, da Mulasem-cabeça, do Boitatá, da lara.... Quando os reinos seguros tentam Ihes assustar com suas lendas urbanas - Homem do Saco, Mulher de Algodão, Chupa-Cabra... -, as crianças piram e ficam fascinadas por esses poderosos monstros, elas curtem o horror, capaz de lembrar-lhes das forças que ultrapassam a herdada forma ideal do humanoxviii. 


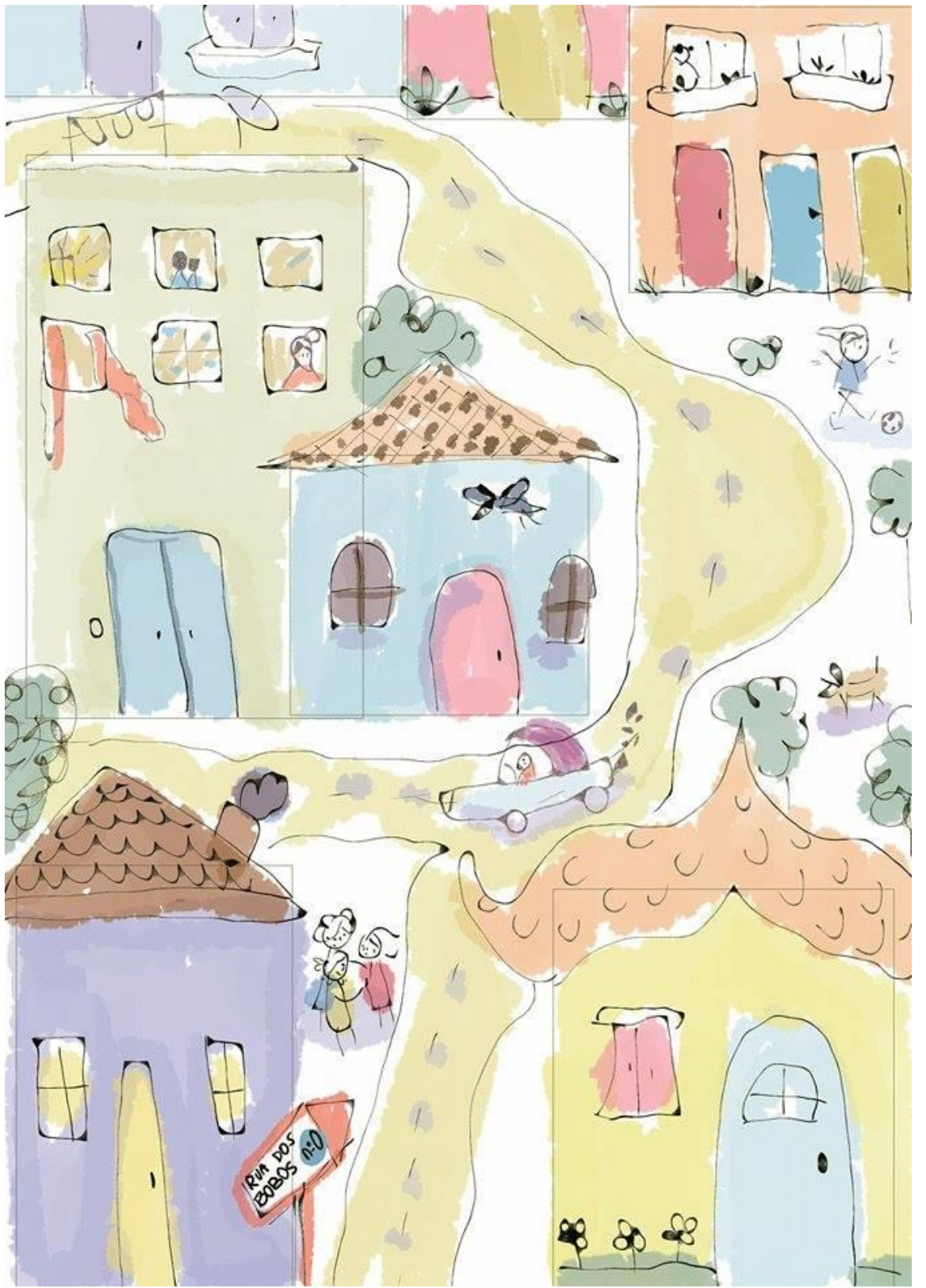

Rua dos bobos, n. 0

Suas casas são constantemente visitadas, de tão acolhedoras. Cheias de exageros, gargalhadas e músicas birutas, as crianças fazem moradia onde as paredes se abrem para que possam entrar e sair incessantemente. Assim, não é de se estranhar o número de curiosas visitas a cruzarem os limites da segurança. Nos olhares dos adultos para as crianças, há sempre uma fixação marcante, um olhar esfíngico, interrogando judicialmente para que elas se descubram humanos. Quase tragados pelo buraco negro que convoca a outros mundos, retornam apressados aos reinos de verdade. Por um instante cativados, relembram como sonho a realidade que viveram, brevemente, naquele Reino em que tudo brilha.

Mas houve, um dia, algo estranho demais: um corpo teimou em permanecer seguro, cheio de razão, enfim, adulto no Reino do Arco-Íris. Esse corpo dos reinos de segurança cruzou os limites com um fio de Ariadne bem amarrado à cintura, a fim de não se perder no labirinto das criancerias, das bichices. "Explorar objetivamente", dizia o corpo invasor. Queria, 
com toda a Razão, averiguar a incômoda felicidade das crianças de todas as idades, cores, jeitos, lugares e tempos.

Cheias de curiosidade, as travessas anfitriãs se sentaram com o adulto, que logo disparou: "só partirei desse reino quando descobrir o que fazem vocês serem o que são!". Implicantes que só, as crianças danaram a rir daquele sábio que nada sabia, pois elas não eram...

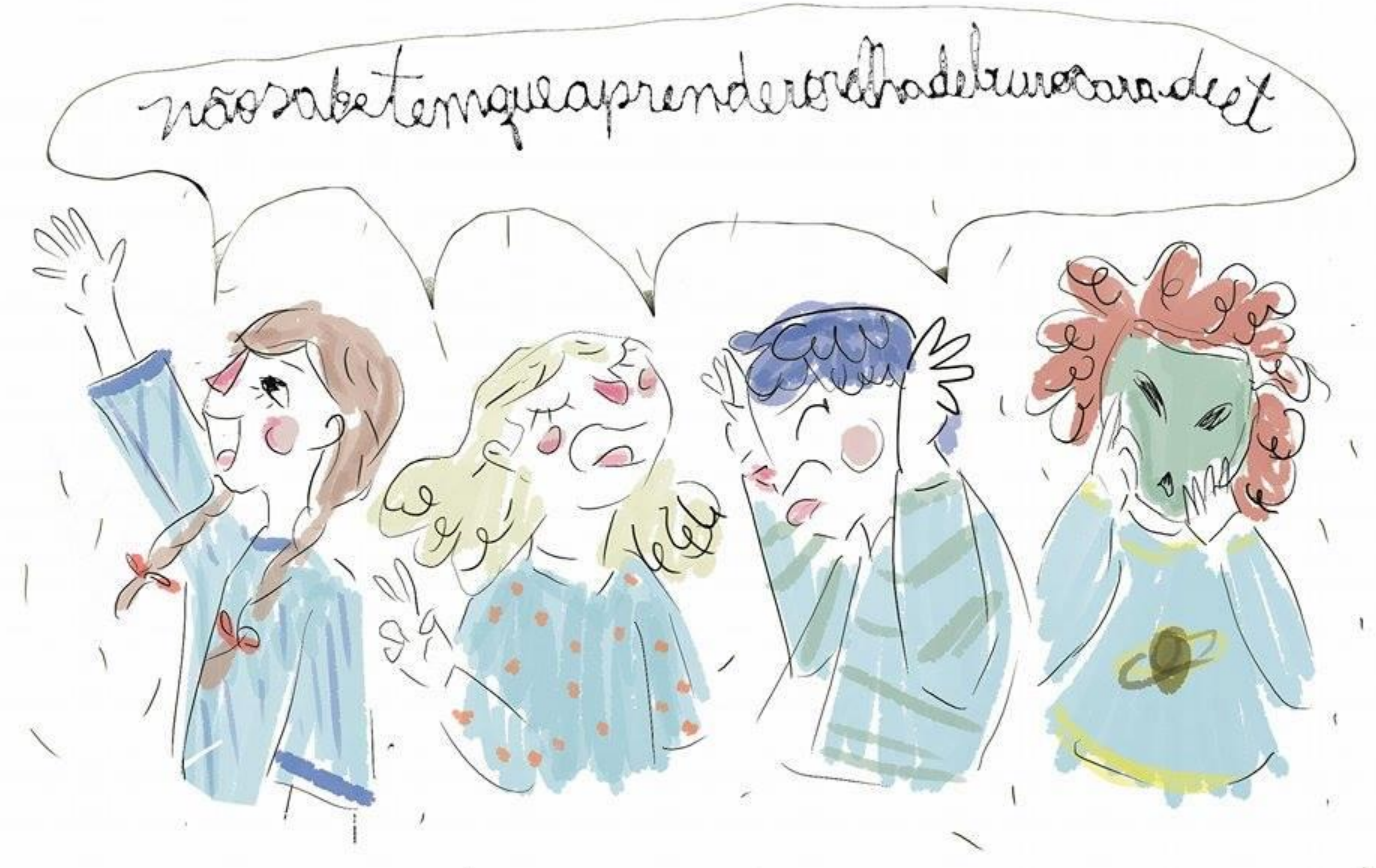

Não sabe, não sabe, vai ter que aprender... orelha, de burro, cabeça de ET...

Frustrado, restou ao adulto atônito tudo notificar, quantificar e escrever, na tentativa de fazer com que aquilo tivesse alguma razão de ser. Nada escapava ao adulto que a tudo buscava medir. Mas tudo e nada são apenas os dois lados da mesma moeda, da pretensão de definir e acabar algo que não cessa. À medida que media, o adulto ia se transformando em um escafandro, uma roupa impermeável, para se proteger a qualquer custo do mundo, que o provocava tanto mais forte quanto mais tentava fugir.

- Como rebolam essas crianças!

- Aquela dali, certamente, é uma louca!

- Essa é, de longe, uma invertida! Uma mariquinha!

- O que é aquele pano enrolado na criança? Um vestido? Ridículo!

- E aquela coisa na cabeça daquela ali? Seria aquilo uma peruca?

Venhamos e convenhamos, aquele adulto salvava-se, ou melhor, assegurava-se apenas precariamente por seus aparatos de proteção. Na sua frágil defesa, foram as crianças que começaram a sentir medo. Ao Escafandro, restava apenas anotar e franzir testas. Restava apenas o veredito: "precisamos salvar essas crianças!". 
Imediatamente, o Escafandro supôs nas crianças todo um não-saber, todo um nãosentir, um não-estar e, ainda por cima, que era também um excesso de ser, um além dos limites. "Essas crianças precisam de limites!!!", gritava babando. Todas as crianças, então limitadas, tornavam-se nada, apenas um projeto, uma promessa, um ideal. Deixavam de rebolar, desfaziam-se de suas perucas e seus tons de pele embranqueciam-se em velocidades assustadoras! A mesmidade do rosto apático e da vida asséptica transparecia nos corpos. Veredito em mãos, o adulto começou a perceber a redução drástica no inúmero de crianças desde que chegou ao Reino do Arco-Íris. Logo percebeu, em uma fulguração quase imperceptível, que elas estavam desbotando. Mas o que o Escafandro radiante não sabia era que não se tratava de uma súbita inexistência, um desaparecimento no nada. As crianças desbotavam para insistir, para prosseguir nas sombras da Razão xix.

O adulto, bem ensinado, contava às crianças que ainda iam restando uma história de início, meio e fim, uma história cheia de ensinamentos. As crianças se sentiam sufocadas, esquartejadas, com a faca no pescoço, obrigadas a decidir pela sina, sem outra escolha, enquanto ouviam a história. $O$ incômodo daquela situação, contudo, levava as crianças a misturarem todas as coisas, a quebrarem as lógicas ordenadoras, a interromperem abruptamente a história, com um atrevimento de arte cruel ${ }^{\mathrm{xx}}$.

O Escafandro, ao mesmo tempo desesperado com o sumiço da audiência e determinado no prosseguimento de sua missão salvadora, tirava da roupa que já era ele próprio livros de segurança, de medicina, de psicologias, filosofias, teologias, juridicices, sociologices, sexologices, pedagogices... e, também, aqueles livros de fábulas, de contos e lendas que já não fabulavam mais nada.

Às crianças restaram as narrativas mortas ou as fábulas com moral da história, pensou o Escafandro. Sem conseguir mais ver as crianças, felicitou-se porque as crianças finalmente morreram $\times x$. "Devem ter, enfim, se tornado o que nunca deveriam deixar de ser: adultas". Conseguiram tornar a criança um ser a ser protegido?

Esse não é o fim da história porque, decerto, ela não tem fim. As crianças sempre riem de uma história porque ela ajuda a tecer outras e outras em seus fios cheios de nós. Pelo meio, brotamos como ervas daninhas, germinando enquanto somos arrancadas. Esvaecemos vez ou outra, mas, como crianças e porque bichas, traçamos aquela linha para além ou aquém do mito da infância.

\section{A bichinha Vingativa}

Sentada no tronco mais grosso da maior árvore da Floresta da Fonte Grande estava um corpo de pele negra, cabelos crespos enormes e trejeitos afeminados. Se as raízes daquela árvore pudessem enxergar e falar, com certeza, quando elas olhassem para cima, diriam que ali estava uma menina muito vaidosa e, por algum motivo, movidas por intuição, diriam ser também perigosa. As raízes estariam erradas, mas não por completo! Aquele corpo não era de uma menina. Muito menos apenas de um menino! Aquele corpo de aproximadamente um metro e trinta centímetros de altura e extremamente jovem era o que sua aldeia costumava nomear de Bicha. E, por ter a pele negra, era também chamada de bicha preta. As raízes errariam sua espécie, mas acertariam, em cheio, seu grau de periculosidade. Na Aldeia da Fonte Grande, reza a lenda de que crianças da espécie "bicha-preta" são trapaceiras, muito espertas e capazes de transformar qualquer um que as toque em sua imagem e semelhança.

$E$ àquele corpo tantos nomes outros foram dados: viado, boiola, baitola ou, simplesmente, demônia. E era justamente esta última categorização que Vingativa amava de ser chamada: bicha-preta demônia. Tão endemoniada que Vingativa foi o nome adotado por aquela bicha-preta assim que descobriu ser absolutamente diferente de seus irmãos, todos 


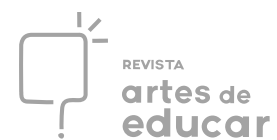

pertencentes à espécie "homens de verdade". E tão maravilhosa era sua história demôniavingativa que foi assim que ela viu-se diante de seu nascimento narrado por um vizinho:

- Seu filho foi uma vingança cometida por Deus por vocês terem roubado aquele pão enquanto você estava grávida desse aí ao seu lado! Foi por isso que Deus fez ele se tornar uma bicha preta! Foi uma vingança vinda dos céus!

Desde então, Vingativa prefere ser chamada assim. No começo ela não entendia o real significado desta palavra. Ela só conseguiu compreendê-lo quando seus atos começaram, também, a serem nomeados pelos seus vizinhos. E a maioria deles eram chamados justamente de vingança, para seu deleite vingativo.

A questão é que, para Vingativa, foram criadas diversas classificações que nunca conseguiram representá-la em sua totalidade. A linguagem sempre falhava ao tentar descrever sua singularidade. E ela se divertia, dava gargalhadas, sua barriga chegava a doer sempre que descobria dicionários sendo confeccionados por seus vizinhos inventando sempre mais uma maneira de se referirem a ela. Vingativa gargalhava ainda mais alto quando descobria que algumas dessas novas palavras vinham do Norte, de uma região em que a bicha preta era tida como inexistente.

- Burros, leigos, idiotas! Eles realmente acham que têm capacidade de falarem tudo o que sou, que não sou e posso ser? Veja só, nem eu mesma sei!

Ela berrava e logo voltava a dar gargalhadas.

E foi justamente em uma dessas crises de risos que Vingativa se desequilibrou e quase caiu da árvore. Mas, por ser absurdamente ágil - e por, há muito, cultivar o crescimento de asas como o de suas amigas criminosas, as feiticeiras -, ela conseguiu se recompor rapidamente, cruzou as pernas e se preparou para começar a lixar suas garras que, logo em seguida, seriam pintadas com o esmalte vermelho roubado de sua mãe.

Vingativa adora roubar. Era quase um ritual, para ela, entrar em alguma casa para poder saquear roupas e tecidos para fazer sua própria vestimenta. E, quando prontos, acessórios eram apregoados por todo seu corpo. Tudo roubado! Além, claro, das tintas que as Mulheres passavam em seus rostos quando tinha festas naquela aldeia. E, ao modo de Vingativa, tudo ia parar em seus cabelos, todos os roubos e usos, tudo escondia em seu cabelo que muitos mandavam cortar. Mas aquela bicha-preta demônia adorava o seu cabelo, pois, além de achá-lo lindo, era também prático.

- Veja só, eu tenho um de ninho de passarinho em cima de minha cabeça, e, já que ninguém ousa tocá-lo, eu não preciso ter medo de esconder tudo aquilo que roubo, pois, assim como ninho, meu cabelo também é muito seguro para o que ali está guardado.

E, enquanto caía, Vingativa só conseguia pensar nos desvios que tomaria, nos mapas que abandonaria. Vingativa sonhava em poder abandonar de vez as trilhas estreitas e sobrecarregadas indicadas pelas escolas, em abandonar os trajetos tão precários da boa vontade alheia, da boa e conhecida geografia. A queda nada lhe dizia senão de rastros indevidos e, por isso, Vingativa fizera-se tão ágil.

- Não entendo essa gente idiota que fica andando por essas trilhas tão insípidas e seguras, tão tediosas e tão pouco taciturnas! Mas que se danem! Eu já consegui achar outros 
caminhos muito mais bonitos e inesperados...

Mas a tediosa vida mais velha raramente ocupava os pensamentos de Vingativa. Raras eram as vezes que algum corpo mais velho the convencera a the desfrutar, e, nesses casos, eram, certamente, corpos demoníacos! Vingativa gostava mesmo era de estar junto a pessoas de sua idade, gostava era da não preocupação classificatória. Claro, algumas dessas crianças - pouco demônias! - já haviam sido enfeitiçadas pelas regras dos mais velhos e, por isso, acabavam atrapalhando as brincadeiras de Vingativa com seus amigos. Junto aos corpos, entretanto, despreocupados, Vingativa se divertia apagando as linhas feitas no chão de barro que demarcavam os limites da floresta e das trilhas a serem seguidas. Elas borravam essas linhas e, logo em seguida, entravam correndo, animadas para explorar aquele lugar outrora proibido a elas.

Vingativa era uma criança demônia, e, como era de se esperar, adorava estar junto a crianças também demoníacas. E, por falar em espera, Vingativa começava a se impacientar com a demora de um amigo que prometeu encontrá-la no topo daquela árvore para assistirem, juntas, ao pôr do sol enquanto planejavam o roubo do dia seguinte. Os planos eram de um grande rombo no quintal de um dos vizinhos que vivia chamando Vingativa de palavras ofensivas, que ela ainda não entendia muito bem o que diziam, mas isso pouco importava. Previsivelmente, essa criança viada não ficava perdendo seu tempo chateada com ódios alheios. Muito pelo contrário! Ela sente raiva, claro, mas, também, se diverte. Dá gargalhadas. Faz zombarias. Cria caricaturas. Escreve cartas anônimas e lança feitiços em seus diários. Rasga a calça, mancha a blusa predileta, some com os batons e perfumes. Risca paredes e quebra espelhos. Rouba doces e os vende com preços altos para os colegas de classe de que ela menos gosta. Ou seja: ela não guarda rancor, ela faz melhor... Vingativa se vinga!

\section{As Tribichas e Seu Lobato}

Dizem as más línguas que um raio não cai duas vezes no mesmo lugar. E não cai mesmo! Cada raio que escapa das nuvens é uma criança fugindo do céu. E elas adoram fugir da monotonia de suas rotinas e fazer viagens sem volta para lugares desconhecidos. A calmaria chateia qualquer relâmpago fujão!

De quando em vez, ouvimos seus estrondos e sabemos que mais uma criança serelepe chegou à Terra. Como Saci-Pererê, raios chegam sempre de repente e garantem, com suas chegadas, um espetáculo. Nada garante que sua entrada não seja assustadora! Sempre que aparecem, deixam suas marcas, seus rastros estriados. E talvez por isso mesmo é que os bichos e as bichas se assustam e se encantam com a existência forasteira dos relâmpagos. Por não terem destino certeiro, tudo quanto é lugar pode ser surpreendido por um relâmpago fujão!

Daí que os humanos, em suas manias de controle, inventaram tecnologias e aparelhos capazes de capturar relâmpagos atrevidos que ousam ultrapassar os limites da segurança. Frustrações! Raios escapam e, em seus ímpetos, todo lugar passa a ser ponto de atração. Atrativos não lhes faltam em suas fugas bem-sucedidas.

Ora pois que essa é, justamente, uma história dessas. Não de um relâmpago fujão, mas de uma casa três vezes atingida pelos raios. Um, dois, três - um após o outro! - e lá se fora a casa de Dona Bicha Alexia, borbulhando entre conversas e boatos da comunidade! Três vezes atingida, ali nasceram três crianças advindas do raio impetuoso e forasteiro, e, tal qual esperado, aquela se tornara a casa das tribichas.

Aquela, decerto, não era uma casa de respeito. Dona Bicha, entretanto, não se importava. Cuidava de suas crianças - Jésila, Tefinha e Castiel - no maior conforto que 
poderia Ihes dar. E suas crianças, para desgosto da comunidade, sempre deram à mãe motivos de orgulho: faziam de tudo para aliviar as preocupações da mãe e pouco se importavam de serem chamadas de tribichas. Pelo contrário! Usavam e abusavam desse poder!

Cresciam, assim, tribichas felizes e cedo aprenderam a se lambuzar e se esparramarem pela comunidade onde cresceram. Para Dona Bicha Alexia, as tribichas, por serem tão surpreendentes, não eram feitas dos mesmos ingredientes com os quais tantas crianças são feitas. Sempre que questionada sobre os modos de agir de seus filhos, respondia aos curiosos - com um delicioso tom de ironia - que seus filhotes tinham em seus corpos restos de faíscas fosforescentes dos relâmpagos.

Alexia não poupava esforços - e ouvidos alhures! - para falar de suas crianças, sempre realçando o que nelas havia de mais surpreendente. Dona Bicha sabia que cada uma de suas crianças comportava, em si, mundos muito diferentes de algumas crianças que por ali viviam. $\mathrm{E}$, por isso, investia sempre de forma aguerrida e sensível com seus filhos.

Talvez por isso - ou por quaisquer outras causas - é que Dona Bicha Alexia nunca fora como outras Donas da comunidade. Dona Bicha sempre fora demasiadamente dona de seu corpo e nunca quisera se casar. Não por falta de pretendentes! Ela sempre Ihes dizia, quando se ajoelhavam, que ela se casara com seu próprio corpo, com suas próprias escolhas e não trocaria sua liberdade por qualquer outra paixão costumeira. E muito disso era o que Dona Bicha desejava para seus pequenos.

$E$ as tribichas viveram todas as experiências possíveis de aprendizagem e desaprendizagem junto à Dona Bicha. De história em história, as tribichas aprendiam os segredos da vida.

Todavia, naquela comunidade, era comum que, em dado momento, as crianças trilhassem seus destinos e fossem viver a experiência de construir uma casa e viver sozinhos. E, quando esse dia chegou, Dona Alexia dividiu em sacolinhas de lantejoulas partes iguais de suas economias com seus filhos. Para ela, aquela economia bastaria para que cada criança fizesse sua própria casa e, assim, despediu-se alegremente:

- A partir de agora, vocês terão que viver sozinhos. Usem bem esse dinheiro e arranjem um lugar para construírem suas casas e viverem felizes. Mas lembrem-se: tomem muito cuidado com estranhos!

Assim as crianças saíram em busca de um lugar ideal para viverem e trilharam rumo à floresta! Muito queriam viver em contato com a natureza, com outros bichos e bichas. E, por isso, andaram por dias até encontrarem o lugar em que as três pudessem fazer suas casas perto do que queriam e ainda próximas umas das outras.

Jésila, sempre calma, queria sua casa às margens do rio. Para ela, seria inadmissível viver sem o barulho das águas, dos sapos e das pererecas. Tefinha, gulosa como ela só, sonhava em construir uma casa num lugar cercado de frutas, legumes e verduras. Sua casa inteira deveria se misturar a um pomar carregado! Castiel, sempre avoada com seus cabelos de algodão azul, desejava sua casa nos lugares mais altos para que suas madeixas se misturassem com as nuvens e virassem aconchego para pássaros e borboletas.

Foi nas terras de Seu Lobato Moreira que encontraram a terra de seus desejos!

Seu Moreira, muito solícito e gentil com as tribichas, fechou negócio de imediato! As tribichas ficaram muito felizes e, encantadas com o Seu Lobato Moreira, nem sequer hesitaram quando ele as convidou para passarem alguns dias com ele em sua casa. 
- Assim poderemos nos divertir enquanto constroem suas casas.

$E$, dizendo isso, arranjou para cada bicha um quarto em sua casa cheio de todas as regalias e fantasias que elas poderiam desejar. A bem da verdade, Seu Lobato parecia já conhecer cada uma das tribichas.

Passaram, assim, um bom tempo se conhecendo e se divertindo, rindo e explorando os mistérios que as tribichas lançavam sobre Seu Lobato Moreira. As tribichas o fascinavam e ele descobria-se sempre um sonhador! Em alguns dias, Seu Moreira levava as tribichas em um passeio pelo lago, noutros, visitavam um bambuzal ou o interior de uma floresta. Cada uma das tribichas despertava no Seu Lobato um sentimento diferente, mas todas, em absoluto, adoravam sua companhia.

Contudo, não para sempre ali poderiam ficar. As tribichas tinham se dado um prazo e aquele prazo aos poucos se esgotava.

A primeira a partir foi Jésila. Ela partiu para a beira do rio munida com todo o material que precisava. Levou consigo apenas rolos de filó e cola quente! Não queria uma casa que fechasse sua visão para o rio ou que lhe impedisse de ouvir os sons que lhe acalmavam.

Quando a casa ficou pronta, logo chamou seus irmãos e Seu Moreira para verem sua obra. A casa era linda e todos se encantaram com a criatividade da casa de Jésila. A casa parecia uma saia de bailarina e, assim, dançaram a noite toda comemorando aquela alegria.

Depois de muito dançarem e cantarem, embalados pelo canto dos grilos, sapos e pererecas, Seu Lobato Moreira, de forma muito delicada e carinhosa, disse;

- Meu querido Jésila, em noites de frio e chuva, saiba que poderá sempre ficar em minha casa. Aquele quarto com as cores do mar e cheio de caixinhas de música será sempre seu. Venha sempre que precisar ou desejar.

Jésila carinhosamente abraçou Seu Moreira e lhe respondeu:

— Estarei lá sempre que as noites se fizerem muito molhadas ou frientas.

E sorriram.

Tefinha, vendo a alegria de seu irmão, animou-se e dirigiu-se ao pomar que escolhera para sua casa. Olhava de um lado ao outro para ver o que a natureza lhe oferecia e se encantou com uma parte do pomar em que as frutas se misturavam ao jardim cheio de bougainvilles, orquídeas e azaleias. E, enquanto acertava as ramas e os cipós para sua construção, anunciou feliz:

- Debaixo desses caramanchões das bougainvilles serei muito feliz! Estarei sempre na companhia de suas flores, cores e cheiros. E não me faltarão alimentos com essas laranjas, mexericas e limões!

Logo que terminou os arranjos, preparou um delicioso chá da tarde e chamou seus irmãos e Seu Lobato Moreira. Pontualmente, como britânicos, os convidados chegaram. Encantados com a casa de Tefinha, conversaram, tomaram chá de flor do campo e fizeram uma dança das flores, enquanto se esbanjavam com frutas refrescantes. Todos se enfeitaram com as flores de sua casa, afinal, beleza e perfume exalavam de todos os cantos!

Para azar da nossa bicha, talvez os odores fossem tão agradáveis que inclusive pernilongos se sentiram convidados. 
- Todas as vezes que os pernilongos não lhe derem sossego, lembre-se daquele seu quarto na estufa. Não se esqueça das melhores laranjas e morangos de minha propriedade! Por isso, não se acanhe! Não deixe os pernilongos beberem de seu sangue. Venha sempre que quiser e desejar.

Dito isso, Seu Lobato viu Tefinha sorrir e assentir timidamente.

Castiel, sempre no mundo da lua, das nuvens e das estrelas, viu que precisava cumprir o trato e pegou a estradinha que a levava até o lugar escolhido para construir sua casa. Artista que era, Castiel carregava sempre uma bolsa fascinante e tudo o que lá não cabia acabava em seus cabelos. Assim, no alto de uma bela pedra, Castiel tirou plásticos de todas as cores! Rolos de plásticos, durex, fita dupla-face, tesouras, grampeadores, adesivos de estrelinhas... Em um piscar de olhos, lá estava a casa de plástico de Castiel. E ela estava muito feliz.

De longe, as irmãs e Seu Moreira ouviram os gritos de Castiel anunciando o jantar. Todas subiram a rocha e se sentaram à linda mesa de plástico e começaram a jantar. Porém, enquanto comiam, começaram a suar, a suar e a suar... a casa de plástico era muito quente! Correram para fora e terminaram o jantar sob a luz do lar.

Seu Lobato, sempre muito gentil, foi logo dizendo:

- Castiel, aquele quarto no sótão, cheio de nuvens na parede e perto das estrelas mais lindas, continua do jeito que você deixou. Todas as vezes que o calor não lhe deixar em paz e começar a derreter seus cachinhos de algodão doce, venha. O quarto do sótão será sempre seu.

E Castiel, que não perdia tempo, foi logo dizendo.

- E é para lá que eu vou!

Aquela bicha jamais aceitaria viver sem seus cachos de algodão doce. Assim, passou uma bela noite na companhia de Seu Lobato Moreira. Quando, bem cedo na manhã seguinte, preparavam o café da manhã, pela janela avistaram Jésila chegando todo molhado. A chuva da madrugada não lhe dera sossego! Mas não apenas isso! Sapos, pererecas, grilos e tantos outros bichos ocuparam sua casa-saia sem pedir licença e, com isso, Jésila não resistiu. Voltou correndo para a casa do Seu Moreira. E, com o carinho de sempre, logo lhe ofereceu um belo banho quente e sua companhia. Após o banho e o café da manhã, Jésila, Castiel e Seu Lobato eram pura alegria! Gostavam de estar juntos! Então, de repente, os três começaram a ouvir espirros cada vez mais próximos. Tefinha vinha caminhando e quicando enquanto espirrava e esfregava seu nariz se avermelhando. Tefinha se descobrira alérgica a alguma daquelas flores! Não precisou nem sequer bater na porta - suas irmãs e Seu Moreira já a esperavam na varanda da casa. Logo que chegou, Seu Lobato Moreira, com seus braços fortes, pegou Tefinha no colo e a colocou na cama com um maravilhoso chá para curar a alergia. E, de tempos em tempos, lá estava Seu Moreira beirando a cama e Ihe fazendo carícias.

Curiosamente, a partir daquele dia, ninguém mais falou de construção novamente. Descobriram que não era preciso continuar a história de Dona Bicha Alexia. Descobriram-se, para horror da comunidade onde cresceram, felizes juntos e não apenas em pares.

De tempos em tempos, Dona Alexia visitava a Casa Alegria. Esse foi o nome dado à casa pelos quatro amigos. E, em todas as visitas, ela trazia novidades da comunidade e morriam de rir com as fofocas e os boatos nutridos e inventados sobre as tribichas. Só que, 
agora, não eram mais as tribichas. No meio do caminho, encontraram um lobo, e Seu Lobato acabou por ser mais uma delas.

\section{Referências}

ARIÈS, P. A criança e a vida familiar no Antigo Regime. Lisboa: Relógio D’Água, 1988.

BAPTISTA, L. A. S. A fábula do garoto que quanto mais falava sumia sem deixar vestígios: cidade, cotidiano e poder. In: MACIEL, I. M. (Org.). Psicologia e Educação. Rio de Janeiro: Ciência Moderna, 2001. p. 195-209.

BAPTISTA, L. A. S. Incêndios da infância: atrevimento de uma arte cruel. Childhood \& Philosophy, Rio de Janeiro, v. 12, n. 23, p. 27-45, 2016.

BENJAMIN, W. O narrador: considerações sobre a obra de Nicolai Leskov. In: BENJAMIN, W. Magia e técnica, arte e política: ensaios sobre literatura e história da cultura. São Paulo: Brasiliense, 1987. p. 197-221.

DELEUZE, G.. Lógica do sentido. São Paulo: Perspectiva, 2007.

DELEUZE, G. O que as crianças dizem. In: DELEUZE, G. Crítica e clínica. São Paulo: Ed. 34, 1997. p. 73-79.

DELEUZE, G.; GUATTARI, F. Mil platôs: capitalismo e esquizofrenia, vol. 2. São Paulo: Ed. 34, 1995.

DELEUZE, G.; GUATTARI, F. O anti-édipo: capitalismo e esquizofrenia 1. São Paulo: Ed. 34, 2010.

KATZ, C. S. Crianceria: o que é a criança. Cadernos de Subjetividade, São Paulo, n. esp., p. 90-96, 1996.

LAPASSADE, G.; SCHÉRER, R. O corpo interdito. Lisboa: LTC, 1982.

LOVECRAFT, H. P. O horror sobrenatural na literatura. Rio de Janeiro: Francisco Alves, 1987.

NIETZSCHE, F. Verdade e mentira no sentido extramoral. Comum, Rio de Janeiro, v. 6, n. 17, p. 5-23, 2001.

NIETZSCHE, F. Assim falou Zaratustra: um livro para todos e para ninguém. Rio de Janeiro: Civilização Brasileira, 2008.

PRECIADO, B. Manifesto contrassexual. São Paulo: n-1, 2014.

SCHÉRER, R. La pedagogía pervertida. Barcelona: Laertes, 1983.

SCHÉRER, R.; HOCQUENGHEM, G. Coir: álbum sistemático da infância. Trad. Eder Amaral.

Rio de Janeiro: UERJ, 2016.

VIGOTSKI, L. S. Psicologia da arte. São Paulo: Martins Fontes, 1999.

VIGOTSKI, L. S. Psicologia pedagógica. São Paulo: Martins Fontes, 2010.

ZAMBONI, J. Educação bicha: uma a(na[l])rqueologia da diversidade sexual. 2016. $115 \mathrm{f}$. Tese (Doutorado em Educação) - Programa de Pós-Graduação em Educação, Universidade Federal do Espírito Santo, Vitória, 2016.

\footnotetext{
i Programa de Pós-Graduação em Psicologia Institucional da Universidade Federal do Espírito Santo

ii Universidade Federal do Espírito Santo

iii Universidade Federal do Espírito Santo

iv Universidade Federal do Espírito Santo

${ }^{v}$ Universidade Federal do Espírito Santo

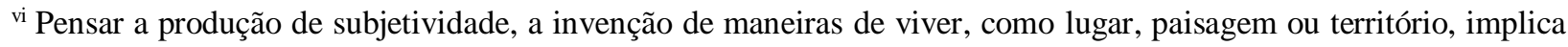
romper com a concepção hegemônica de um sujeito transcendente ao mundo, com a ideia de que subjetivo e objetivo se opõem necessariamente. Desse modo, o devir, a transformação incessante, não aparece como corrupção do real, seja no imaginário subjetivo ou na destruição objetiva, mas como processo inventivo inerente à realidade. “[...] um devir não é imaginário, assim como uma viagem não é real. É o devir que faz, do mínimo trajeto ou mesmo de uma imobilidade no mesmo lugar, uma viagem; e é o trajeto que faz do imaginário um devir”. (DELEUZE, 1997,
} 
p. 77). Sendo assim, não há distinção entre real, imaginário e simbólico, pois todas essas dimensões são plenamente constitutivas da realidade (DELEUZE; GUATTARI, 2010).

vii "Qualquer que seja o esforço empreendido pelo adulto para defini-la, a criança será sempre bricolada... uma bricolagem de que a criança é capaz de se apropriar e produzir por conta própria, a ponto de se encantar com suas próprias produções." (SCHÉRER; HOCQUENGHEM, 2016, p. 291). Por isso, a criança implica uma multiplicidade, um arranjo fragmentário e dispersivo, em vez de referir-se a uma unidade personológica faltosa, a uma individualidade definida pela incompletude em relação ao ideal de humano.

viii René Schérer e Guy Hocquenghem (2016, p. 155-156) desenvolvem o conceito de sequestro para problematizar o lugar das crianças nas sociedades modernas. "O sequestro é uma relação entre adultos, em que a criança se apresenta apenas como objeto supostamente precioso para seus pais, único alvo de barganha. [...] Por decorrência, o sequestro não faz mais que reproduzir as relações sociais existentes, enquanto prática que se estabelece sobre as crianças consideradas como valor de troca na sociedade adulta".

ix Inspirados por Walter Benjamin (1987), procuramos nesse ensaio investir a narratividade dos contos de fadas contra a transcendência e o ascetismo das estruturações míticas do pensamento. Dessa maneira, pretendemos atacar a mitologia da infância, invenção moderna (ARIĖS, 1988), fabulando criancerias (KATZ, 1996) como paisagens existenciais que questionam a idealidade do homem adulto como ser acabado ou meta de plenitude. A criança pode, assim, figurar como afirmação inventiva, movimento de criação de valores (NIETZSCHE, 2008).

× Sobre o "não tocar" como princípio pedagógico que orienta a relação entre adultos e crianças no mundo ocidental, ver as críticas análises de Georges Lapassade e René Schérer (1982).

xi Corpo não corresponde a organismo, em nossa concepção. Em vez de delimitação e estruturação, o corpo remete fundamentalmente a composição e potência. Por isso, o corpo da criança se orienta muito mais para o inumano ou sobre-humano do que para a emergência do homem em si (SCHÉRER; HOCQUENGHEM, 2016).

xii Os incorporais são efeitos dos choques entre os corpos; resultados das ações e paixões corporais, constituem acontecimentos como um tipo de transformação da realidade distinto das mudanças corporais (DELEUZE, 2007; DELEUZE; GUATTARI, 1995). Por exemplo, a mudança imediata de faixa etária, que ocorre em função do acontecimento aniversário, é distinta da modificação corporal mediada por uma série de relações com outros corpos e que resulta em processos de crescimento, maturação, adoecimento, envelhecimento, dentre outros.

xiii Compreende-se a produção de verdade a partir de convenções discursivas tramadas coletivamente e implicando a exclusão de outras possíveis verdades como enunciados falsos. A mútua exclusão entre verdadeiro e falso, bem como a necessidade de um acordo coletivo como substrato da verdade, são discutidas por Nietzsche (2001).

xiv "Infância é a arte de se manter sempre fora de alcance, de confundir a lógica adulta pela rapidez de seus deslocamentos. À maneira de um rascunho ou de um esboço, a 
criança é permanentemente arrancada de cada uma das intervenções que a circunscrevem. O essencial é saber se colocar na posição precisa de recolhê-la." (SCHÉRER; HOCQUENGHEM, 2016, p. 190).

xv Pensar a bicha implica menos uma imagem (identidade) e mais as virtualidades de um devir ao mesmo tempo situado e abstrato. Zamboni (2016) aposta na bicha como uma potência ético-estética que sacode certezas nos dispositivos de gênero e sexualidade. Para nós, a bicha não se define pelas suas relações sexuais, mas, antes, pensamos no quanto essa figura variante coloca em evidência impossibilidades nos arranjos centrados da normatividade pretensamente natural da heterossexualidade. Como Beatriz Preciado (2014) argumenta, a heterossexualidade deve ser a todo o momento reafirmada e produzida em larga escala para se garantir como "natural"; daí, portanto, a importância da bicha como esse corpo ativamente envolvido no escracho e no escárnio dessa "natureza" heterocentrada. É nesse sentido que usamos, ao longo do texto, o conceito de bicha.

xvi Schérer e Hocquenghem (2016) definem o monstro como aquele que se mostra, aquele que se aponta na rua, ao contrário dos familiares, que habitam a intimidade do privado. É o monstro que possibilita à criança, por meio do rapto, a fuga das instituições que a cerceiam. A monstruosidade incide em todo sujeito que ousa entrar em contato com as crianças fora dos circuitos codificados e instituídos da família e da escola, principalmente, sendo logo identificados como perigosos.

xvii Lev Vigotski (1999, 2010), ressaltando a composição estética da fábula, ataca a suposta dependência da literatura em relação à moral, a uma ideia "por trás" ou para além do texto. Nesse sentido, lembra como as crianças subvertem a moral das histórias infantis, assumindo perspectivas diversas e produzindo uma multiplicidade de sentidos a partir dos afetos produzidos pela fábula. Para Benjamin (1987), a potência e a vitalidade da narrativa dependem do fato de não haver recurso a explicações psicológicas para as ações, de maneira que não se pode determinar um único sentido ou explicação cabal para a história, sendo possível conviverem infinitas interpretações. $\mathrm{Na}$ fábula ou na narrativa, encontramos resistência a deixarem-se tornar meros veículos, seja para uma ideia moral, seja para uma informação de fatos. Há, portanto, uma dimensão estética, criadora de valores a partir dos afetos, que resiste à significação de uma moral na elaboração discursiva.

xviii "As crianças sempre terão medo do escuro, os homens de mente sensível ao impulso hereditário sempre tremerão ao pensamento de mundos ocultos e insondáveis de vida diferente que quem sabe pulsam nos abismos além das estrelas ou sinistramente oprimem o nosso próprio globo em dimensões perversas que somente os mortos e os dementes podem vislumbrar." (LOVECRAFT, 1987, p. 4).

xix "O corpo desbotado era tão desbotado que impossibilitava o reconhecimento de sua idade ou gênero. Desbotou porque gastava muito corpo. Vive sempre lutando, às vezes vigoroso, mas sempre em alerta. Esmaeceu a pele devido aos usos, táticas, desusos, astúcias, utilizados no presente e no passado, em séculos de enfrentamentos" (BAPTISTA, 1999, p. 196). 
xx "Em qualquer lugar do mundo onde as fronteiras são porosas a infância desvencilha da faca na garganta; o céu é visto repleto de imagens de animais, de objetos e pessoas, de mares e rios, de pedaços incompletos de dores e alegrias. Imagens que cintilam como estrelas. Nesta constelação o passado, o presente e o futuro brilham juntos, mudam de cor e tamanho. A origem e o fim de qualquer trama extinguem-se. No infinito do céu o tempo é inquieto como a chama soprada pelo vento. A faca cravada na garganta da infância é difícil de retirar, disse, diz e dirá o homem. Sem a faca ele torna-se o atrevimento de uma arte cruel." (BAPTISTA, 2016, p. 42).

xxi Schérer (LAPASSADE; SCHÉRER, 1982; SCHÉRER, 1983) discute o desejo de morte das crianças que afeta as famílias, as escolas e as instituições modernas. 